\title{
Spatio-Temporal Distribution of Landslides in Java and The Trigerring Factors
}

\author{
Danang Sri Hadmoko, ${ }^{*}, 2$, Franck Lavigne ${ }^{2}$, Junun Sartohadi ${ }^{1}$, Christopher Gomez ${ }^{3,4}$, Daryono ${ }^{5}$ \\ ${ }^{1}$ Faculty of Geography, Universitas Gadjah Mada, Yogyakarta, Indonesia \\ ${ }^{2}$ Université Paris 1 Panthéon-Sorbonne \& Laboratoire de Géographie Physique, UMR 8591 CNRS, Meudon, France \\ ${ }^{3}$ UCR3 - Risk, Resilience \& Renewal, Waterways: Centre for Freshwater Management, College of Science, Department of \\ Geography, University of Canterbury, private bag 4800, Christchurch 8140, New Zealand \\ ${ }^{4}$ Graduate School of Maritime Sciences, Kobe University, Higashinada-ku, Fukae-minamimachi 5-1-1, \\ 658-0022 Kobe City, Japan \\ ${ }^{5}$ Meteorological, Climatological and Geophysical Agency, Jl. Angkasa No. 1-2, Kemayoran, Jakarta, Indonesia \\ ${ }^{*}$ Corresponding author (e-mail: hadmoko@ugm.ac.id)
}

Received: 30 March 2017 / Accepted: 13 April 2017 / Published: 30 April 2017

Abstract. Java Island, the most populated island of Indonesia, is prone to landslide disasters. Their occurrence and impact have increased mainly as the result of natural factors, aggravated by human imprint. This paper is intended to analyse: (1) the spatiotemporal variation of landslides in Java during short-term and long-term periods, and (2) their causative factors such as rainfall, topography, geology, earthquakes, and landuse. The evaluation spatially and temporally of historical landslides and consequences were based on the landslide database covering the period of 1981 - 2007 in the GIS environment. The database showed that landslides distributed unevenly between West Java (67\%), Central Java (29\%) and East Java (4\%). Slope failures were most abundant on the very intensively weathered zone of old volcanic materials on slope angles of $30^{\circ}-40^{\circ}$. Rainfall threshold analysis showed that shallow landslides and deep-seated landslides were triggered by rainfall events of $300-600 \mathrm{~mm}$ and $>600 \mathrm{~mm}$ respectively of antecedent rainfall during 30 consecutive days, and many cases showed that the landslides were not always initiated by intense rainfall during the landslide day. Human interference plays an important role in landslide occurrence through land conversion from natural forest to dryland agriculture which was the host of most of landslides in Java. These results and methods can be used as valuable information on the spatiotemporal characteristics of landslides in Java and their relationship with causative factors, thereby providing a sound basis for landslide investigation in more detail.

Keywords: landslides, spatio-temporal distribution, causative factors, Java, Indonesia.

Abstrak. Pulau Jawa, salah satu pulau dengan kepadatan pendududuk tertinggi di dunia, rawan terhadap bencana longsorlahan. Kejadian longsorlahan dan dampaknya cenderung mengalami peningkatan sebagai kombinasi antara faktor alami maupun faktor manusia. Terkait dengan permasalahan tersebut maka penelitian ini bertujuan untuk menganalisis: (1) variasi spasiotemporal kejadian longsorlahan di Jawa dalam jangka pendek (bulanan, tahunan) maupun jangka panjang dan (2) faktor yang berperan terhadap kejadian longsorlahan tersebut antara lain hujan, topografi, geologi, gempabumi dan penggunaan lahan. Evaluasi sejarah kejadian longsorlahan dan dampaknya baik secara keruangan maupun menurut waktu dilakukan dengan periode kejadian antara tahun 1981 - 2007. Analisis ambang batas curah hujan menunjukkan bahwa tanah longsor dangkal dan tanah longsor yang mendalam dipicu oleh hujan kumulatif antara $300-600 \mathrm{~mm}$ dan > $600 \mathrm{~mm}$ yang terjadi selama 30 hari berturut-turut. Banyak kasus yang menunjukkan bahwa longsorlahan tidak selalu dipicu oleh hujan dengan intensitas tinggi pada hari kejadian longsorlahan tersebut. Campur tangan manusia memainkan peran penting dalam kejadian longsorlahan melalui konversi lahan dari hutan untuk lahan pertanian, yang merupakan wilayah dimana sebagian besar longsorlahan terjadi. Hasil mapupun metode yang digunakan dalam penelitian ini merupakan informasi yang berharga dalam mengenali karakter 
spatio-temporal longsorlahan di Jawa dan faktor yang mempengaruhi, sebagai informasi dasar dalam investigasi dalam skala yang lebih detail.

Kata Kunci: longsorlahan, distribusi spasiotemporal, faktor penyebab, Jawa, Indonesia.

\section{Introduction}

Landslides are known to be very hazardous phenomena, especially in the mountainous area of the humid tropics. They are also a cause of high risks, in terms of economic losses, casualties, and environmental problems (Iida, 1999; Schuster and Highland, 2001; Dai et al., 2002; Spiker and Gori, 2003; Zhou et al., 2003; Petely et al., 2007, Hadmoko et al., 2010; Hadmoko et al, 2017). The understanding of spatio-temporal characteristics of landslides such as frequency, magnitude and human consequences has recently become a topic of major interest for geoscientists, as well as for governments, non-governmental organisations and local administrations in many regions of the tropics (Paudel et al., 2007; Devoli et al., 2007). These data are vital for quantitative estimation of landslide hazards, in order to calibrate predictive models and to validate temporal predictions (Brunsden et al., 1995, Samia et al., 2017).

In this contribution, we analysed the relations between landslides occurrence and their triggering factors over a long period (27 years) in Java. With 120 million inhabitants and a population density of 900 inhabitant/ $\mathrm{km}^{2}$, Java (which is located in the centre of the Indonesian archipelago) (Figure 1), is the most populated Indonesian Island. It represents $60 \%$ of the Indonesian population on only $6.9 \%$ of the country's surface (BPS, 2005). This population settlements' disequilibrium within the physical environment occurring on steep and unstable slopes is the source of numerous problems on landslides.

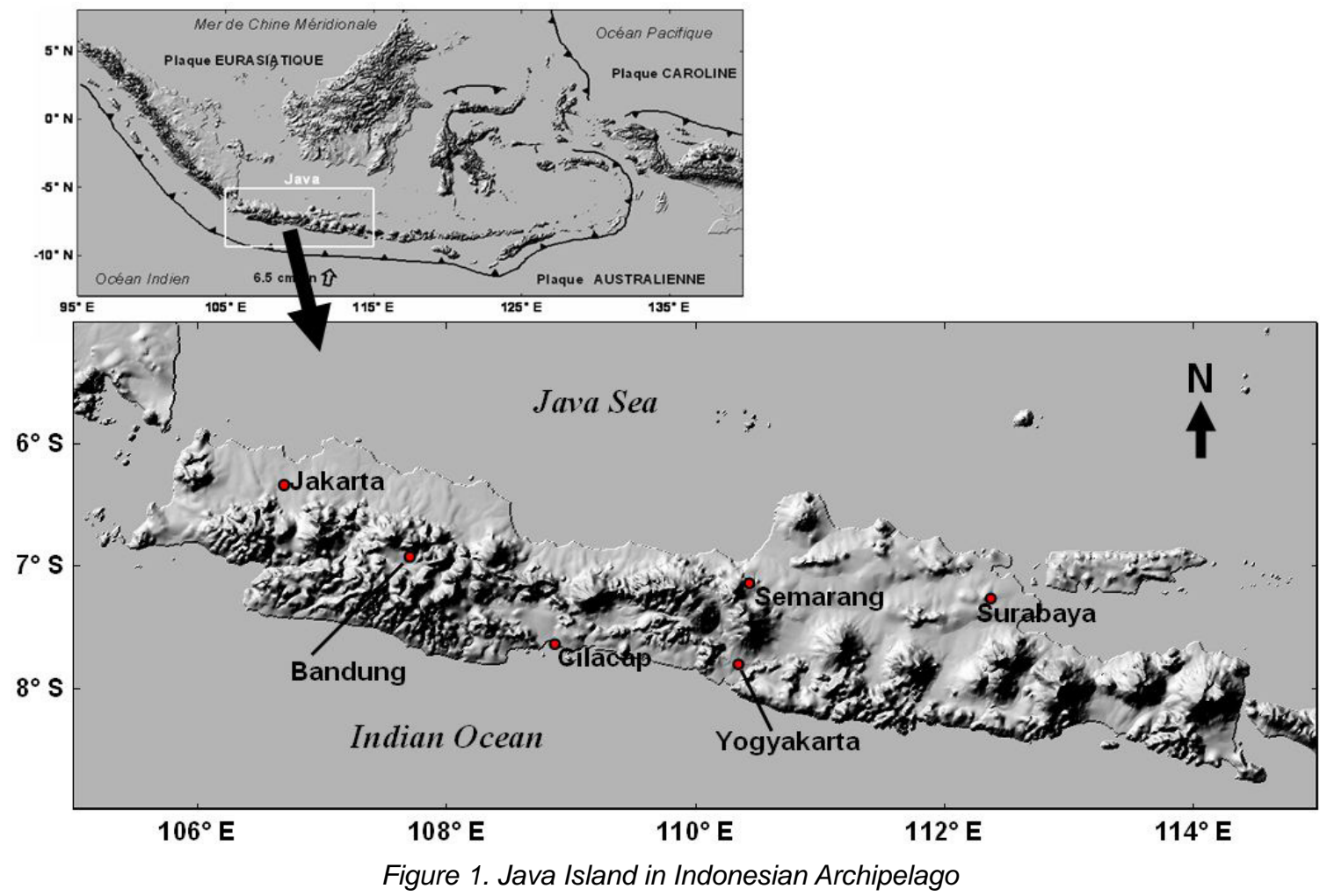

As a result of its geological setting, topographical characteristics, and climatic characteristics, Java is the region most exposed to mass movements in Indonesia, due to several factors: (1) located on a subduction zone, $60 \%$ of Java is mountainous (Hadmoko, 2006), with volcano-tectonic mountain chains and 36 active volcanoes out of the 129 in Indonesia, and these volcanic materials are intensively weathered (2) Java Island was shaken by more 
than 200 earthquakes ranging from 5 to 9 on the Richter scale from the $19^{\text {th }}$ century to the mid-1980's (SEASEE, 1985); (3) Java is under a humid tropical climate associated with heavy rainfall during the rainy season from October to April. Most of the landslides occur during this period (Ayala, 2004; Gabet et al., 2004). In addition, seismic activities are believed to be potential triggering factor in this area (Saputra et al., 2016). On top of these "natural" conditions, the human activity is an additional factor of landslide occurrence, driven by a high demographic density.

Within this setting, the goals of our study were twofold: (1) to collect and analyse spatial and temporal data of landslide occurrence for the period 1981-2007; (2) to evaluate the main landslide causative factors, i.e., rainfall, topography, geology, earthquakes, and landuse. Our paper provides a new insight into our understanding of landslide mechanisms in the humid tropics, and a basis for predicting future landslides and assessing related hazards at a regional scale (Zhou et al. 2002). The results from this paper should be valuable for decision makers and communities with respect to future landslide risk reduction programs.

\section{Methods}

\section{a. Database on landslides events}

For the period 1981-2007, we compiled data on landslide occurrence from various sources: the Indonesian Centre of Volcanology and Geological Hazard Mitigation (CVGHM) and the Research Centre for Disasters at Universitas Gadjah Mada (PSBA-UGM) provided data for 1216 landslide events. On top of these official sources, we added 87 additional data from internal reports, monographs, bulletins and national and local newspapers (Kompas, Jawa Pos, Kedaulatan Rakyat, Republika, Bernas, etc). As a whole, our database documents 1303 landslide events in Java. Data include the date of occurrence, the type and magnitude of the event, the number of victims, the infrastructure affected, and the economic losses for each event. We plotted these data on a base map and compiled all tabular data by using Geographic Information System (GIS). In order to analyze the spatial distribution of landslides by provinces, we then plotted the location of landslide events in a 1: 100,000 scale GIS divided into 3 regions, i.e. West Java (Banten Province, DKI Jakarta Province and West Java Province), Central Java Region (Central Java Province and Yogyakarta Special Province) and East Java Region (East Java Province).

\section{b. Database on triggering factors}

Rainfall data were collected from 1034 rain gauges distributed all over Java. These data were obtained from several governmental institutions such as the Meteorological, Climatological and Geophysical Agency (BMG), the Directorate of Water Resources of Ministry of Public Works (Puslitbang Air DPU), and the Ministry of Forestry. We also used unpublished data from the hydrological and meteorological laboratory in Faculty of Geography, Gadjah Mada University. All rain gauges were plotted in a GIS in order to relate their location to the closest landslide. Unfortunately, the hourly rainfall data is not available in our archive database. Therefore we only used the daily rainfall to calculate rough rainfall thresholds of landslide occurrence.

Topographical data at the scale of the whole Java Island were obtained through a DEM that we built using SRTM data at a $90 \mathrm{~m}$ resolution. We used this DEM to analyse the landslides distribution general trends at a regional scale. We also calculated slopes angles with ILWIS®, and grouped them into seven classes ranging from $0^{\circ}$ to $>60^{\circ}$. Then we calculated the number of landslides for each class.

Seismic data were collected for the period 1833 - 2006 at the BMKG and CVGHM offices. This set of data only concerns earthquakes that caused infrastructure damages and casualties. We organised the data attributes in order to provide automatic plotting for our GIS, and find quantitative relations between seismic activities and landslides. We also compared the landslide activity with low magnitude $(<4$ on the Richter scale) earthquakes data for the period 1990 - 2002.

Land use and vegetation cover data were collected at the Ministry of Forestry, and, further, 
digitalized into a GIS. We completed these data through a combination of aerial photographs, panchromatic SPOT images and Landsat TM images.

After this initial compilation and the preliminary data processing, we carried out a multi-temporal analysis of the behavior of landslides and their causative factors at three different scales: (1) on a yearly basis, we analyzed the general trend of landslide events over 27 years; (2) on a monthly basis we analyzed the relations between landslides and time inferred factors, such as cumulative rainfalls, earthquakes, etc.; (3) and on a daily basis, we worked on landslides triggering rainfalls.

\section{Result and Interpretation}

a. Temporal distribution of landslides

1) Inter-annual variation

During the period 1981-2007, the annual landslide frequency varies significantly from 13 to 90 events per year, with an average of 49 events per year. We can observe three main trends in the landslides occurrence since 1981: (1) a first period from 1982 to 2000 when the number of landslides increases significantly, with a maximum of 90 events recorded in 2000 , and (2) a second period with fewer landslides - 29 in average - with a decline from 2000 to 2004 and (3) third period with the landslide increasing from 2004 to 2006 (Figure 2).

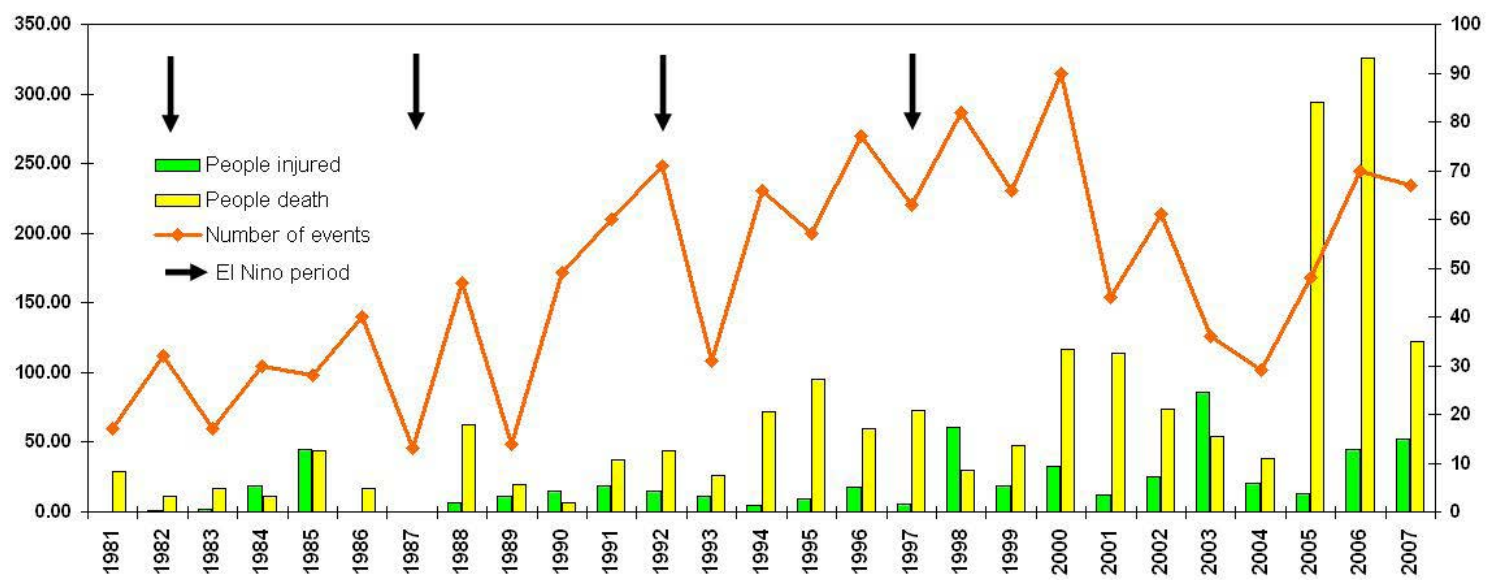

Figure 2. The chart of the annual distribution of recorded landslide events in the period of $1981-2007$ (red line, righthand scale) and their impacts on human losses (bar, left-hand scale).

The fewer number of landslides during 1981- 1990 compared with those other periods was mainly associated with lower of demographic pressures, and less development activities. Human intervention in the landscape was relatively low due to the reduced population numbers in Java. Development activities in several sectors such as infrastructures, settlements and roads were not intensive.

However, since 1990s landslides occurrences increased rapidly due to the rapid increase of population and the economic development. Over exploitation of natural and land resources occurred in order to support human needs and development. Excavating hillslopes for road development and settlement construction, as well as deforestation on many parts of volcanic slopes for agriculture areas increased rapidly. These activities extend into the upper part of mountainous areas due to the full land occupation on the lower part of the island.

An obvious example is given by the flanks of the Sumbing and Sindoro volcanoes in Central Java. Since 1997, high deforestation rates (600 ha/year) result from the upslope expansion of tobacco fields by local farmers. As a result, subsistence crops have also been progressively pushed upslope towards the steeper areas, with poor terracing or shelter planting systems and consequent exposure 
to increased landslide hazards. The trend is similar on the volcanic slopes of East Java where the forest areas drastically decreased between 1990 and 2000 (Lavigne and Gunnell, 2006).

Several natural and human factors should be analysed in order to explain the wide range of landslide fluctuation during the years of 2000 and 2007. Decreasing of landslide occurrence during 2000 - 2004 was probably caused by the decreasing of annual precipitation in Java and the strict governmental regulation on land management. Several projects related to conservation measures have been implemented by the government in order to minimise environmental degradation such as the encouragement of farmers to substitute tobacco for coffee trees on the slopes of Mts Sumbing and Sindoro and reforestation by using teak trees in Cilacap (Lavigne and Gunnell, 2006). However, such programmes are sometimes unsuccessful, deforestation and over-cultivation are still occurring in Java. Teak forests were logged and replaced by young $30-\mathrm{cm}$-high pine saplings and subsistence crops such as peanuts, cassava, sweet potatoes and banana plants on steep slopes.

\section{2) Intra-annual variation}

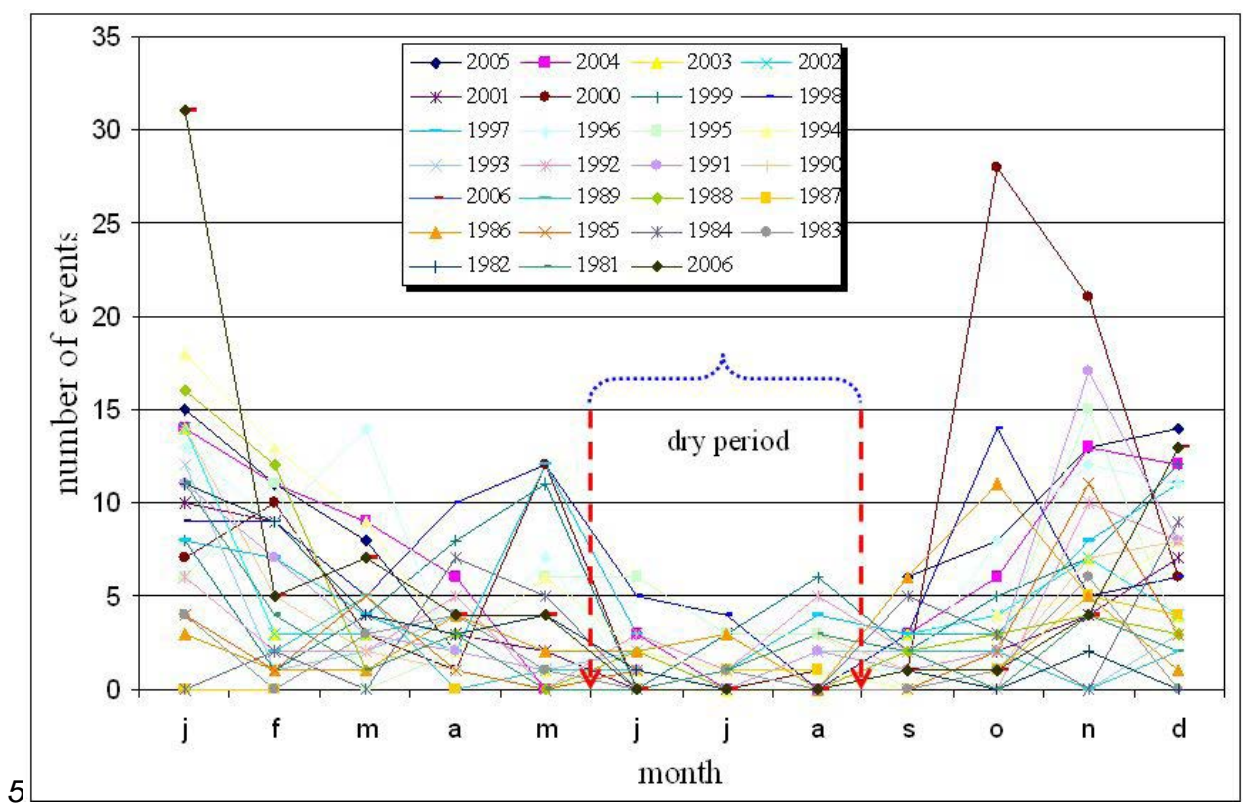

Figure 3. Monthly variation of landslides in Java during the period $1981-2007$. January is the most abundant period with an average of nine events, whereas July has the fewest events (one in average).

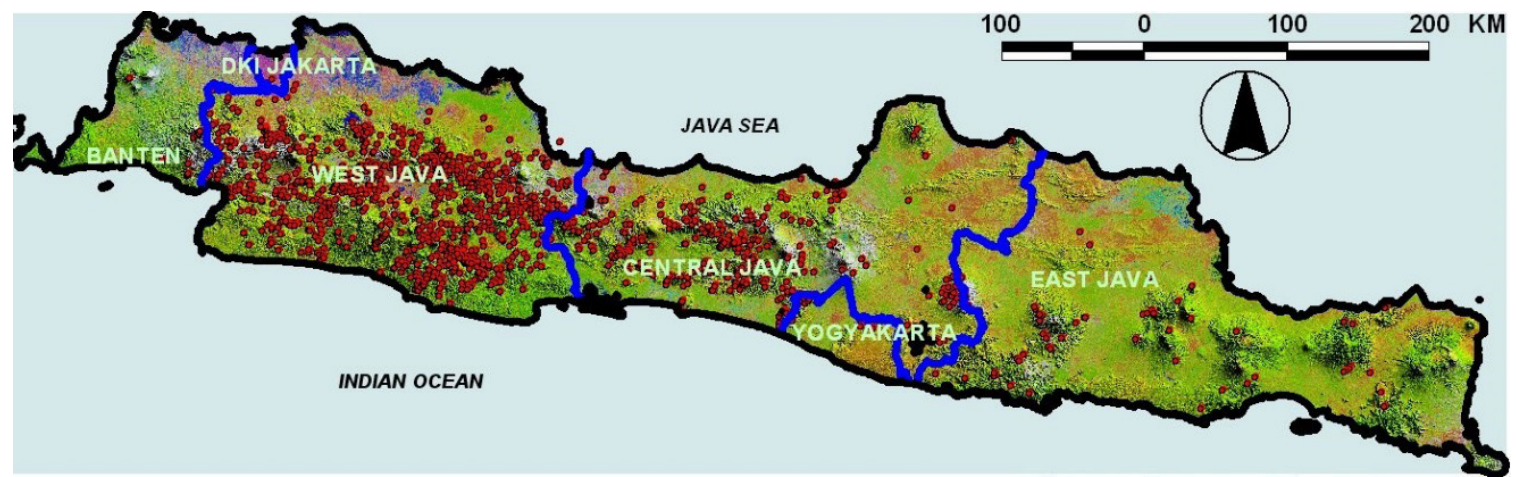

Figure 4. Spatial distribution of landslides in Java during the periods of $1981-2007$. Red dots indicate the locations of landslide events.

b. Spatial distribution landslides and West Java Region (67\%), followed by Central Java causative factors analysis

The landslides are unevenly distributed in $(29 \%)$ and East Java (4\%). The overall landslide density in Java reached $1 \times 10^{-3}$ events $/ \mathrm{km}^{2}$ with Java (Figure 4). Most landslides are concentrated in the annual average was $3.6 \times 10^{-4}$ event $/ \mathrm{km}^{2} /$ year. 
This spatial distribution of landslides is therefore combined with their causative factors i.e. topography, rainfall, geology, earthquakes and land use. Spatial analysis of each causative factor was conducted separately in order to understand the role of each factor to landslides triggering.

\section{1) Landslides and topography}

Java Island is mainly represented by slopes ranging from $0^{\circ}$ to $10^{\circ}(28.5 \%)$. Those that exceed $60^{\circ}(0.84 \%$ only $)$ are located on the upper volcanic slopes and along mountain escarpments (Figure 5). In general, slope gradient has an influence on landslides events. The number of landslides increases significantly from slopes inferior to $10^{\circ}$ and from 30 to $40^{\circ}$. We also found the overall positive correlations between slope angle and landslide density, although they are not very strong. The highest density of landslides can be found on slopes ranging from $40^{\circ}$ to $50^{\circ}(0.021$ events/ $\mathrm{km}^{2}$ ). However, inverse correlation between landslides events occurs on slope steepness more than $40^{\circ}$ (Figure 6) when the landslide frequency tends to decline with an increasing of slope angle.

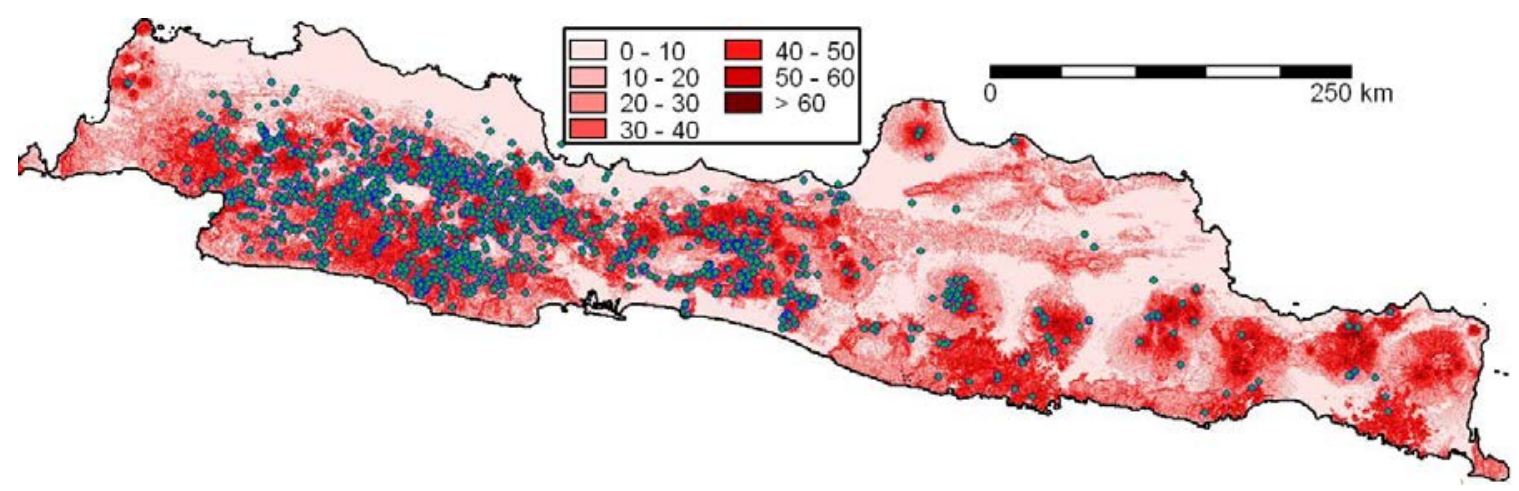

Figure 5. Spatial distribution of landslides (blue dots) based on a slope map (in degree).

The positive correlation between and development activities within this slope landslides and topography for the slope range range. The steeper slopes $\left(>40^{\circ}\right)$ can be more of $30^{\circ}$ to $40^{\circ}$ is due to the force influence of slope stable due to the existence of resistant bedrocks gradient, combined with the unconsolidated and consolidated materials. These areas usually colluvial materials of volcanic origin which can consist of non-arable land leading to the fewer fail easily, very intensive human occupation human activities.
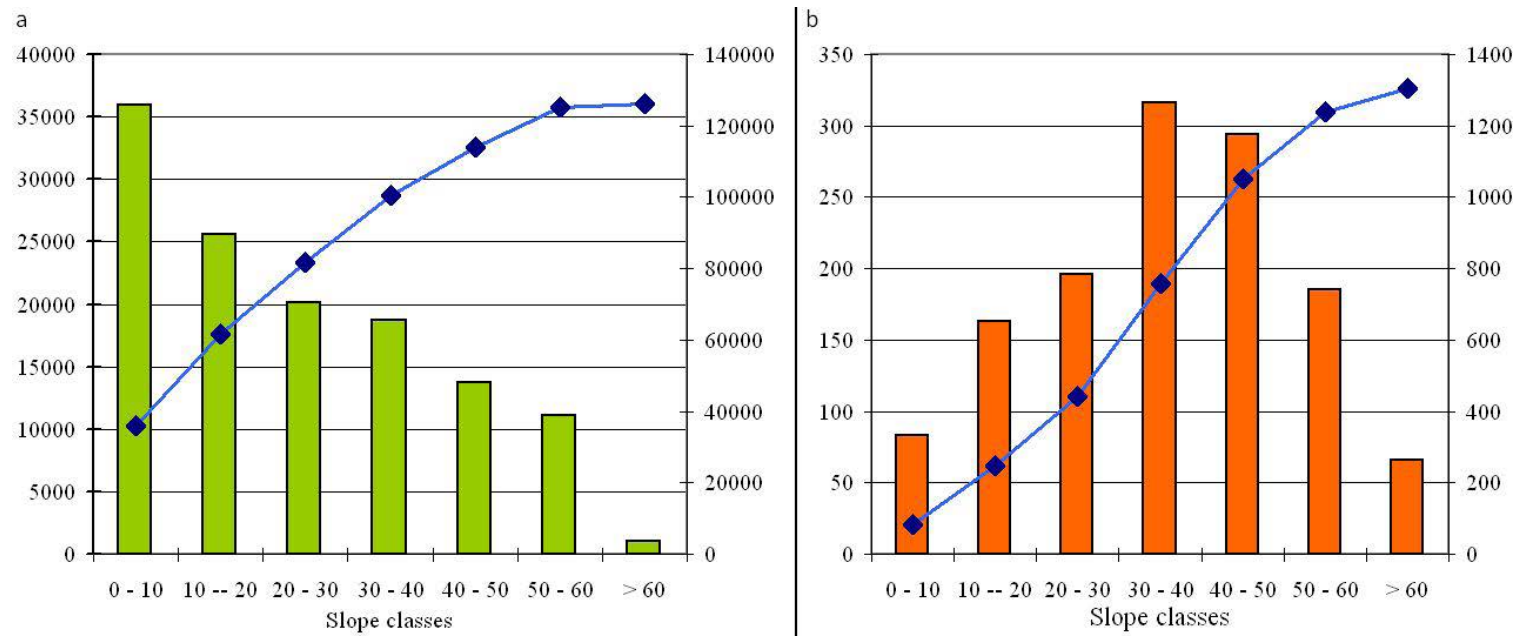

Figure 6. a) Areal ratio of each slope class (bar graph, left-hand scale) and cumulative area of slopes; b) Frequency of landslide in each slope classes (bar graph, left-hand scale) and cumulative frequency of landslides (line graph, right-hand scale). 


\section{2) Landslides and rainfall}

Figure 7 displays the spatial variation of the rainfall distribution in Java. The amount of annual precipitation is significantly higher in West Java than further East, decreasing with a constant $\mathrm{W}-\mathrm{E}$ gradient. This gradient also corresponds to the landslides distribution, with $67 \%$ of the events located in West Java. The minimum annual rainfall occurs in the northern part and in far East Java, where few landslides can be spotted (Figure 7). On the other hand downpours concentrate on relief such as the volcanic upper slopes and the intermountain basin like in the Bandung Basin- West Java, which is the host of numerous landslides and heavy rainfall (Figure 7). Landslides are mostly located in areas with $2000 \mathrm{~mm}$ to $2500 \mathrm{~mm}$ of annual precipitation, which cover the largest amount of land in Java (Figure 8). The surface area of each rainfall class decreases from the interval of $2000 \mathrm{~mm}$ to $2500 \mathrm{~mm}$ with increasing and decreasing of annual rainfall (Figure 8).

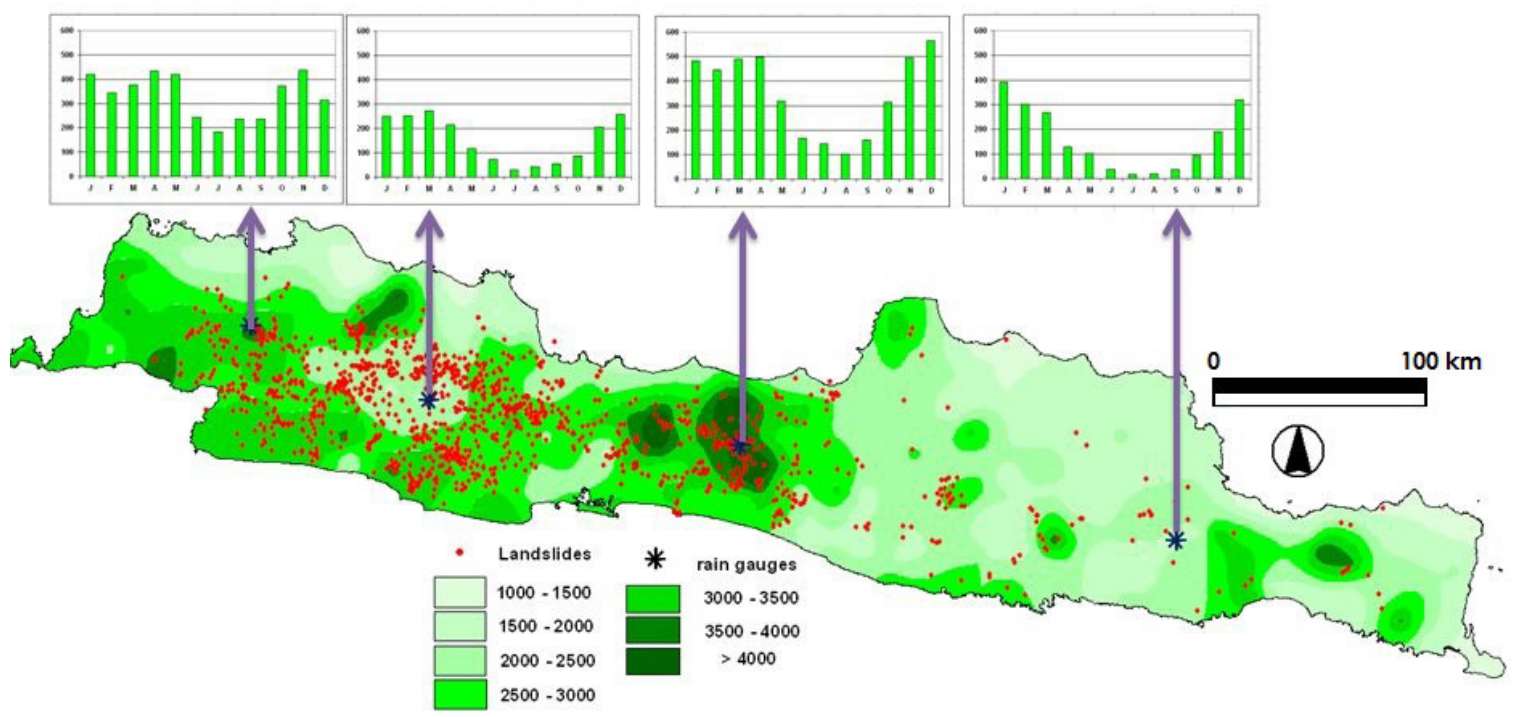

Figure 7. Spatial variation of annual rainfall in Java Island and landslides occurrence (red points). Bar charts show a monthly variation of rainfall in four selected rain gauges with the maximum scale of $600 \mathrm{~mm}$. This map is based on a calculation of average annual rainfall of 1034 rain gauges distributed in Java during 20 years. Rainfall intensity was classified into seven classes with the interval value of $500 \mathrm{~mm}$.

Overlaying the annual isohyets with the landslides distribution indicates that the landslides occurrence increases concomitantly with the precipitation until the class 2500 $3000 \mathrm{~mm}$. However, the numbers of landslides decrease with increasing of precipitation value on more than $2500 \mathrm{~mm}$. Only a few landslides occur under these high intensities rainfall. This variation shows that the largest area of Java Island is rained by $2500-3000 \mathrm{~mm} /$ year, which covers the middle and upper part of volcanic and structural mountains and several areas of Bandung Basin. This area usually consists of weathered materials which can fail easily. Several factors should be taken into account to explain the fewer frequencies of landslides on more humid area (> $3000 \mathrm{~mm}$ / year) such as: the area of this rainfall interval is smaller than others that cause smaller probability of landslides, this area is usually covered by consolidated bedrock and better land management (forest area).

On a shorter time-scale, cumulative rainfalls play an important role in landslide triggering. Most of the shallow landslides can be associated with antecedent rainfall reaching $300 \mathrm{~mm}$ for the 30 days that precedes the slope failures, and rainfall superior to $43 \mathrm{~mm}$ on the day of landslide occurrence. There is an inverse relation between antecedent rainfalls and daily rainfall. Indeed heavy instantaneous rainfall can produce a landslide with the help of only low antecedent rainfall. On the contrary we encountered 11 cases of landslides with no 
rain on a triggering day, but with important antecedent rainfalls (Figure 9). For example the landslides of Tawangmangu Sub-District, East Java, occurred after a period of heavy antecedent rain (more than $175 \mathrm{~mm} /$ day) with no rainfall at the time of the failure. Thus antecedent rainfalls increase the soil moisture content and the ground water levels. This phenomenon also plays an important role for deep-seated landslides, since nine of them, that occurred in Menoreh Mountains on November $6^{\text {th }}, 2000$, are the response of $839 \mathrm{~mm}$ antecedent rainfalls during the 30 days that preceded the events.

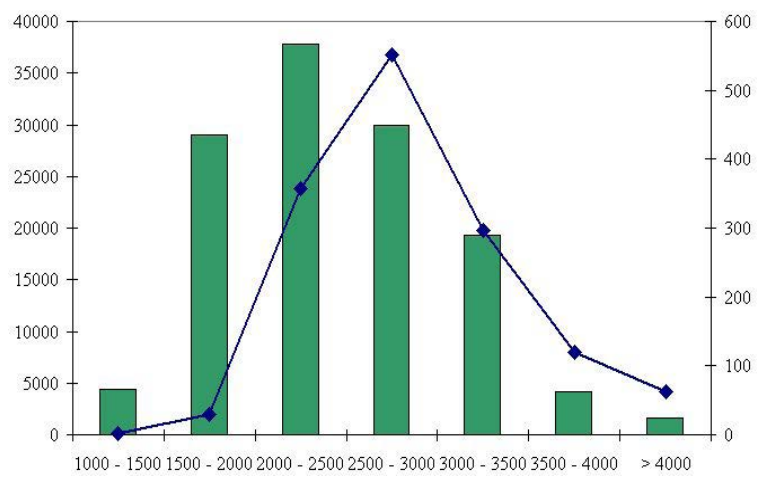

Figure 8. The surface area of each annual rainfall interval (bar graph, left-hand scale) and landslides distribution in each class of annual rainfall in Java (line, right-hand scale).

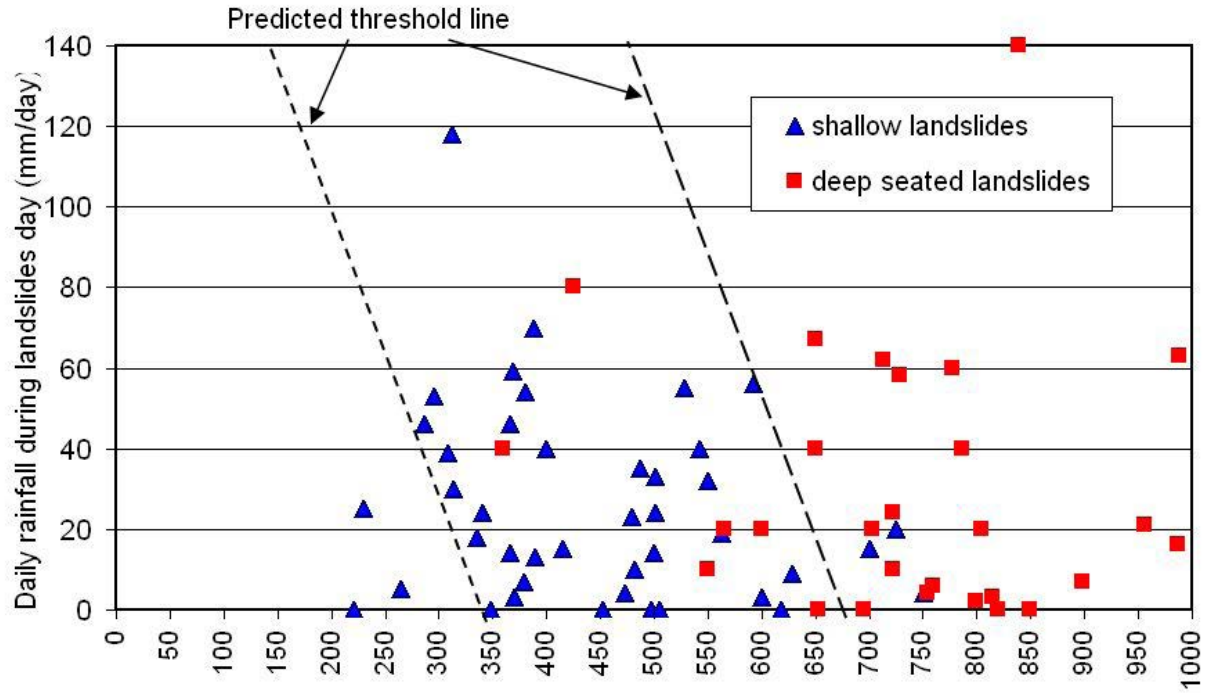

Antecedent rainfall during 30 days $(\mathrm{mm})$

Figure 9. Chart showing the relation between antecedent rainfalls during 30 consecutive days and daily rainfall during landslides day.

3) Landslides and seismic activities

Forty catastrophic earthquakes were reported in Java during 1833-2006, with magnitudes ranging from 4.8 to 7.2 on the Richter scale (DVGHM, 2006). The distribution of epicentres (Figure 10) Central Java. shows that most of the earthquakes events occurred in West and Central Java, and only a few shook East Java. This distribution reflects the occurrence of faultline, which are also concentrated in West and 


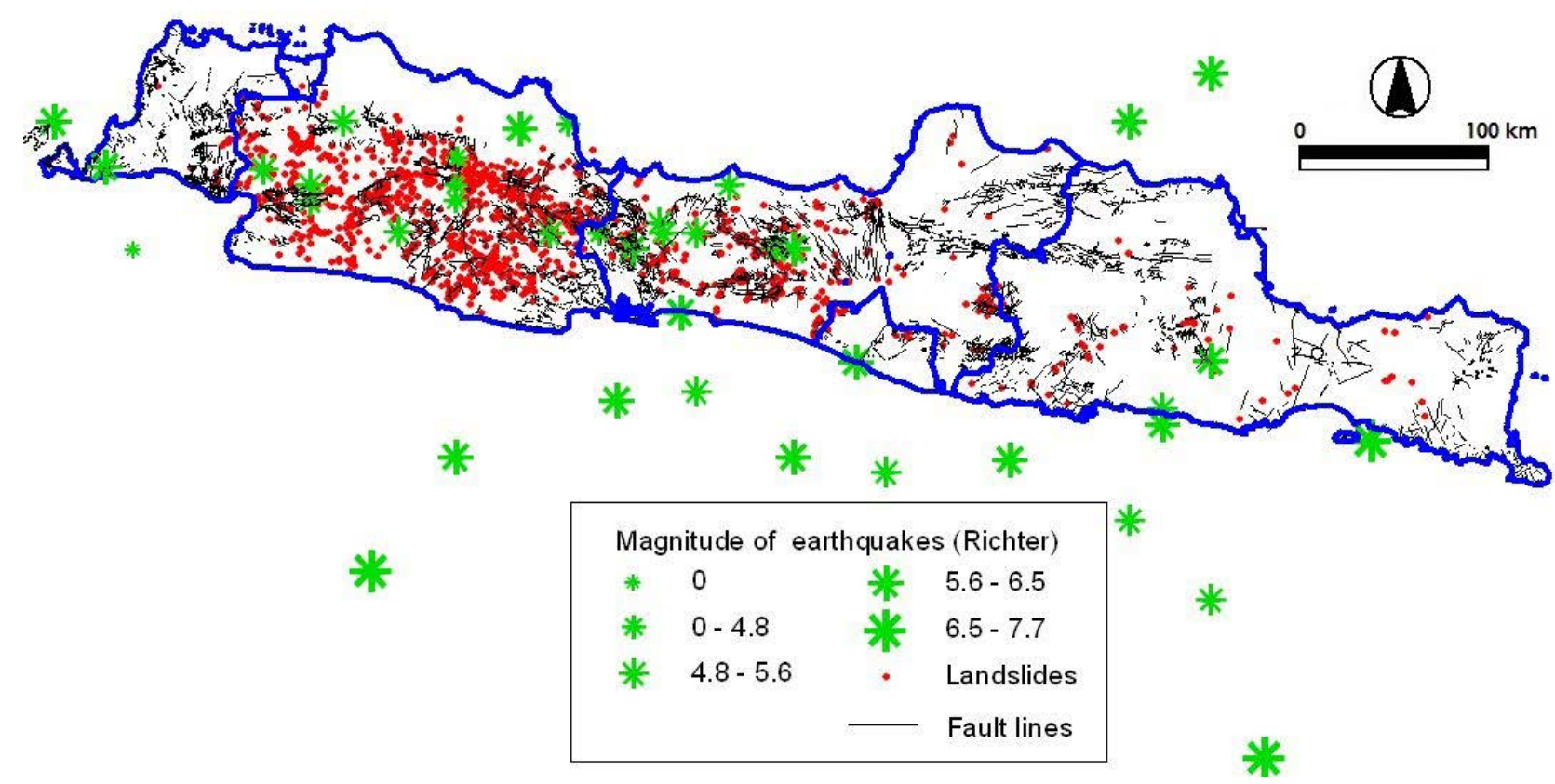

Figure 10. Spatial distribution of earthquakes in Java during 1833 - 2006

Earthquakes are an important triggering factor for landslides. They rupture the rock materials which were already fragile. The spatial distribution of earthquakes in Java corresponds with the concentration of landslides, which most of them spread out in West Java. Big earthquakes can directly cause landslides in several part of Java. Several big landslides occurred in Majalengka District, West Java on July $6^{\text {th }}, 1990$. These landslides were directly caused by an earthquake (5.8 Richter) during in the middle of dry season when the precipitation was zero (DVGHM, 2006). The big earthquake that occurred in Bantul, Yogyakarta Province in May 2006 caused a lot of soil cracks along the southern range south of Yogyakarta. More than 20 points of landslides were identified along the southern mountain in Bantul which face to Northwest and Southwest (Figure 11).

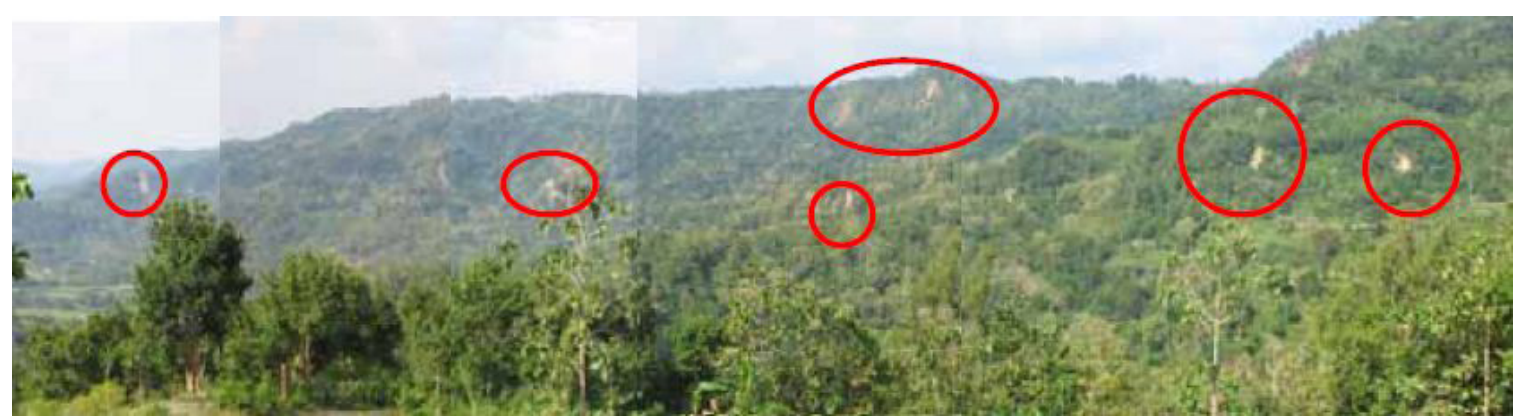

Figure 11. Shallow landslides occurred along southern mountains of Yogyakarta after earthquakes on May $28^{\text {th }}, 2006$.

An example from Menoreh Mountains in Central Java shows that the trend of seismic activity usually coincides with the landslides occurrence (Figure 12). However we need to be circumspect in analysing the data, because there is a lapse of time between the seismic tremor and the landslide occurrence. Indeed seismic activity during the dry season will favour landslides for the next rainy season. For example, we registered 1115 seismic vibrations in 2000, with only 10 landslides on that year. 


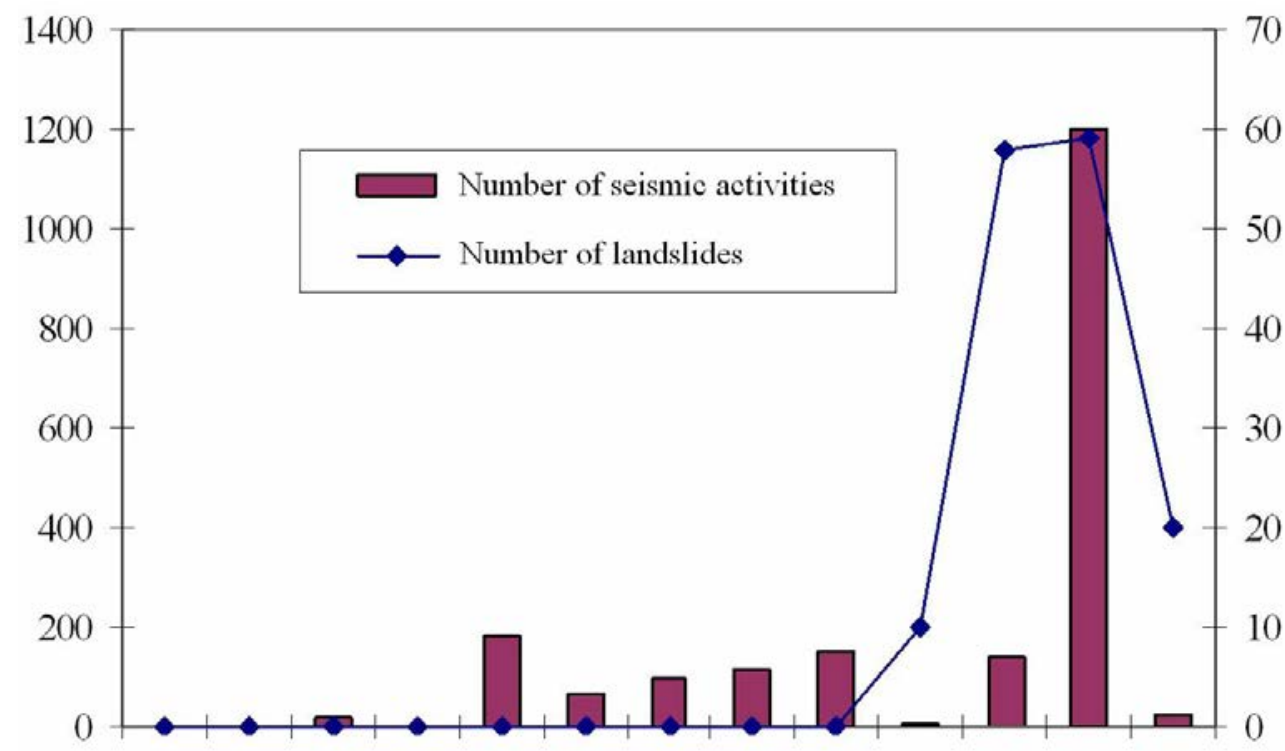

1990199119921993199419951996199719981999200020012002

Figure 12. Relation between the number of earthquakes (bar graph, left-hand scale) and shallow landslides activities (line graph, right-hand scale) during the period 1990 - 2002 on Menoreh Mountains, Central Java Indonesia.

4) Landslides, land use and human activities

Thirteen of land use types were mapped in Java Island (Figure 13). Dryland agriculture spread largely on the wide range of topography from lowland to upper part of the mountainous area from West to East while the artificial forest occupies only the middle and upper part of volcanic slopes. Paddy field usually covers the alluvial plain and intermountain basin. This island is mostly covered by dryland agriculture, followed by paddy field and artificial forest which represent of $47.7 \%$, $21 \%$, and $13.8 \%$ respectively of total surface of island.

Classification of landslide activities based on land use type shows that most of the landslides occur on dryland agriculture, followed by paddy fields and artificial forests with respectively $66 \%, 18 \%$ and $7 \%$ of the total number of landslides (Figure 14). These data indicate that human activities play an important role on landslide occurrence. Dryland agriculture covers not only the lower part of land, but also reached middle and upper slopes; with terraces agriculture that often accelerates landslide triggering (Lavigne and Gunnell, 2006). Most of dryland agriculture and paddy field were previously forested lands that have been logged (Figure 14). Geomorphic impacts were almost immediate: the first heavy rainfall following the land cover change triggered several shallow landslides, and this has recurred every year during the rainy season since 2000 (Lavigne and Gunnell, 2006). For these classes, the vegetation is not deeply rooted in the ground, and they are often accompanied by numerous landslides. However, artificial forest was classified into $3^{\text {rd }}$ rank for landslides occurrence. This area was established with the reforestation conducted by the government which consists of the young vegetation whose roots unable to penetrate deeply into the soil.

The increase of demographic pressure also forced people to invest in the least cultivable land extending to the tops of slopes with the extremely steep slopes. During 1980 - 2005, the Java population increased from 91 to 128 million, amounting to an increase of $40 \%$ during 25 years. Of this population, $45 \%$ concentrated in West Java Region (including Jakarta and Banten Province). This population increase was known as a significant factor initiating and accelerated landslide in this region mostly by undercutting and removal of the toe of slopes for the cutting of roads, houses and agricultural area. 


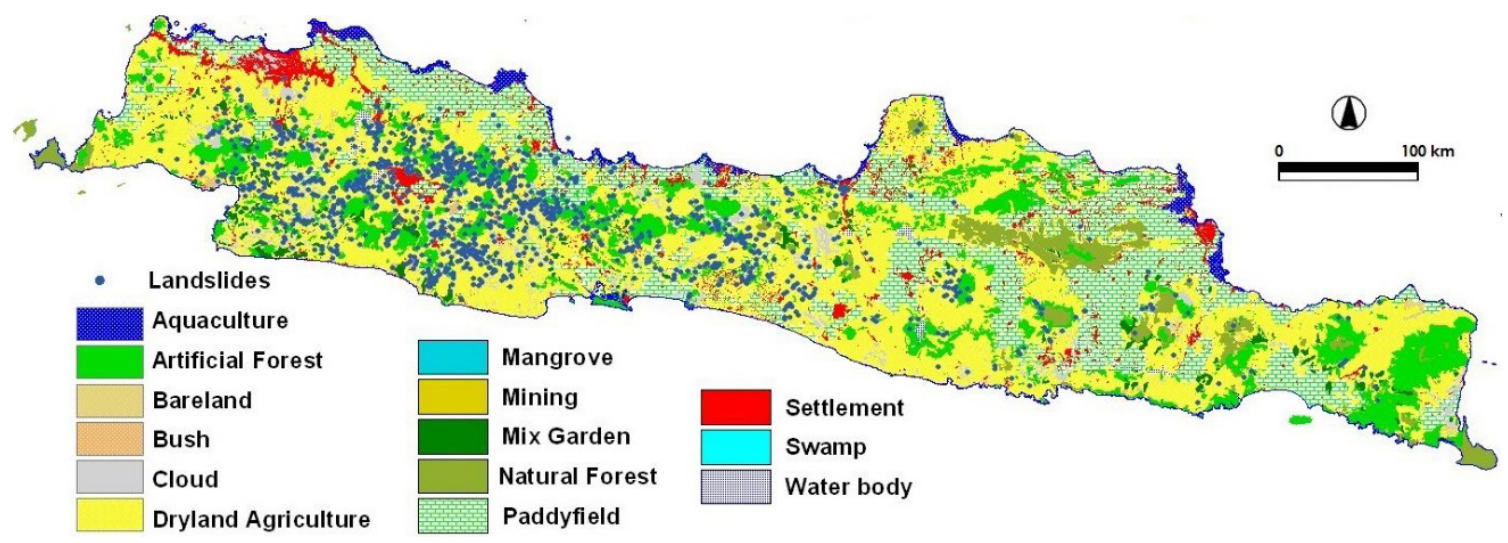

Figure 13. Land use type in Java Island combined with landslides points

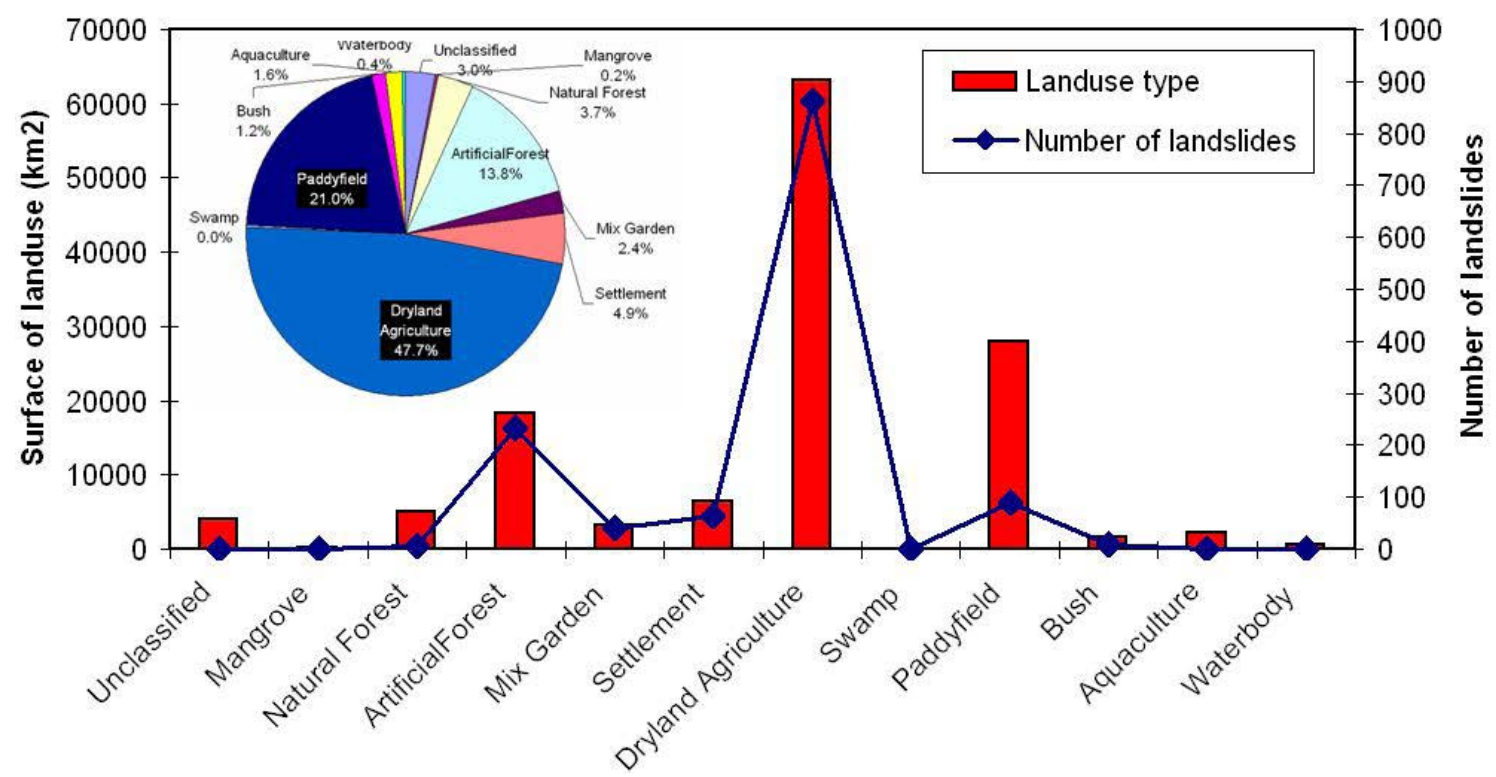

Figure 14. Land use type of Java and landslides activities with the percentage of land use type (circle chart), surface of each type of land use (in $\mathrm{km}^{2}$ ) (bar chart) and distribution of landslide based on land use types (line chart).

\section{c. Human impacts}

Over 27 years, landslides casualties reached 1848 people and 550 injured people. The casualties' analysis over time varies significantly from one year to another. Indeed the landslide death toll increased significantly from 1999 to 2001 and from 2003 to 2006. The five most deadly years occurred after 2000 in 2000, 2001, 2005, 2006 and 2007. The increasing of casualties was probably caused by the increasing of population staying in the hazardous area. The highest death toll occurred in West Java, and the lowest victims were noted in East Java. The different number of casualties of each region correspond closely with the number of landslides that occurred.

Landslides also affected houses, building, roads, agricultural land and irrigation drainage infrastructure. During 27 years, the numbers of houses destroyed and damaged by landslides were 2078 and 9821 respectively, and 2078 families had to be evacuated temporarily. The affected agricultural land and roads were estimated at approximately 4,229 ha and 12.3 $\mathrm{km}$ respectively. It was estimated that 67,000 families had to be evacuated because of the destruction of their houses and the hundreds of villages were threatened. It can be also estimated that the annual economic losses in Java would exceed one million Euros. The highest estimated economic losses occurred in the years of 2002 and 2003, reaching 2,185,400€ and 1,816,900 € respectively (Hadmoko, 2006).

Our data show that the occurrences of catastrophic landslides in Java tended to increase in recent years, and in recent times 
have caused much higher of casualties than before. The increasing human losses reflects the densification of human occupation on land mostly in hazardous area both for settlement or agriculture area. Over-cultivation and houses construction on upper slopes aggravate landslides occurrences. Indeed, the death toll is much higher than injured peoples, this phenomenon was caused by the fact that landslides occurred extremely fast in terms of velocity during a short period (less than 15 minutes). Moreover, the majority of the landslides occurred during the night, and in densely populated villages, consequently the population has no enough time to be evacuated.

One of example of catastrophic landslides was in December 26 $6^{\text {th }} 2007$ when landslide occurred sporadically at 17 locations of Tawangmangu District on the western slopes of Lawu Volcano. These landslides occurred in densely populated mountainous area which killed 71 people and destroyed 15 houses. Others example of catastrophic landslides events (in terms of number of person killed) are (1) the debris flow which occurred in Pacet Subdistrict, Mojokerto District, East Java, on December 11, 2003 and killed 32 persons and (2) Kadungora landslide in the District of Garut, West Java, on January 28, 2003 and 20 person were buried.

\section{Discussion}

Java Island lacks an integrated spatiotemporal landslides investigation which covers overall area of the island during three different timescales: short, medium and long-term periods. Most previous research conducted in Java has only focused on the specific areas with a short record of temporal data. Impacts of landslides in Java are also increasing with time, but until now there has been little or no quantitative data to support this view, or to explain the causes of the increases. This research highlights two dimensions: temporal evolution of landslides and its spatial distribution and together with factors causing landslides.

This contribution provides an analysis of relevant information for all Java. We provided a long series of data consisting of 1303 landslides affecting Java Island between 1981 and 2007 with the high temporal variation. Landslides occurrences are much higher compared to others parts of the world such as in Himalaya Nepal and Italia. In Himalaya Nepal, 397 catastrophic landslides were recorded during the periods of 1978 and 2005 (Petley, et al. 2007) while In Italia, there were 996 fatal landslides recorded for the whole country during 1410 to 1999 (Guzzetti, 2008). Landslides density in Himalaya is also much lower compared to Java Island with the density reached $2.7 \mathrm{x}$ $10^{-3}$ event $/ \mathrm{km}^{2}$. This comparison indicates a chronic problem to landslides hazards in Java which has to be minimised.

Temporal variation of landslides in Java reveals a great variation in different timescales. In the long-term scale, landslides events increase with a great yearly fluctuation and regular seasonal variation. This variation reflects the change of triggering factors over time such as rainfall, earthquake and human pressure. Long-term occurrence of landslides corresponds with the annual rainfall which greatly varies from one year to another influenced by conditions such as El-Nino and La-Nina events. Also, this long-term evolution is greatly influenced by increasing human pressure in Java. Development processes and over-cultivation on marginal land by people could be the reason for the increasing landslides and their casualties. Intra-annual distribution of landslides has a close relationship with the monthly distribution of rainfall as an effect of monsoon variation in Java Island which leads two different seasons i.e. wet and dry season that change regularly during six months in the year.

Landslide events were spatially distributed unevenly, being concentrated more in West Java Region and becoming less in Central Java and East Java (Figure 4). This phenomenon is closely related to the environmental setting of West Java. Landslides were distributed on wide ranges of slope gradients with the highest concentration on slope range $30^{\circ}-40^{\circ}$. Most of them were well scattered on all types of terrains on middle and upper parts of volcanic forms (Figure 4 \& Figure 6). These parts are 
characterised by steep slopes, high relief, and the presence of pyroclastic materials, volcanic ashes, and andesitic lava flows that are very intensively weathered and fractured, and therefore deeply eroded. Landslides occur on all type of land use mostly on dryland agriculture, artificial forests and paddy field (Figure 12).

We found that most of landslides concentrate on the interval slope of $30^{\circ}-40^{\circ}$ and decrease both with increasing and decreasing of slope steepness. This result is slightly similar with those of Zhou et al. (2002) on Lantau Island, Hongkong, who found that the frequency of failures is highest on moderately steep terrain with gradient ranging from $25^{\circ}-35^{\circ}$. Paudel et al. (2007) also correlated the landslides and topography on Mt. Aso, Japan and pointed out that slope interval of $30^{\circ}-35^{\circ}$ is the most exposed area to landslides. These results are explained by two factors: (1) the existence of an unweathered concrete materials covering the steeper slopes on upper part mountains with the low thickness of soil, slightly prone to landslide generation; and (2) human pressure on land (agriculture, infrastructure, road network) generally take place in flatter terrain and up to $30^{\circ}-40^{\circ}$. Steeper slopes are relatively virgin from human activities due to remoteness, and impracticalities of agricultural development.

Besides these, both cumulative rainfalls during certain periods and rainfall intensity are widely recognised as important roles on landslide triggering. However there has been some debate as to the relative role of antecedent rainfall and daily rainfall. Experiences from various regions of the world have resulted in different conclusions as to the significance of antecedent rainfall for slope instability (Raharjo et al., 2001). We pointed out that for most landslides occurrences, the daily rainfall threshold decrease with increasing rainfall accumulation (Figure 8). Smaller amounts of daily rainfall are needed to trigger landslides as increasing of cumulative rainfall (Crozier, 1999; Gabet et al., 2004). However, there were several contradictory results regarding daily and cumulative rainfalls in Java. Some landslides can be produced with less than $300 \mathrm{~mm}$ of antecedent rainfall, without any rain shower during landslide day, and vice versa. Therefore we should take into account the characteristics of the land (e.g. soil thickness, cracking on soils, slope steepness, land use type) and the depth of failure plane in our analysis (Paudel et al. 2007).

Variation of rainfall threshold is also be produced by the depth of failure plane. The threshold conditions for failure of shallow landslides are not necessarily determined by the development of positive pore pressures on a potential slip plane. Failure conditions can also occur when, at a critical depth, the moisture content in the soil becomes close to saturation triggered smaller amount of rainfall, resulting in a considerable reduction of soil strength (van Asch et al., 1999). In the other hand, deeper landslides are in most cases triggered by positive pore pressures on the slip plane induced by a rising groundwater level. The groundwater rising requires much more input water in order to establish infiltration, percolation and soil saturation. This means that deeper landslides need larger absolute amounts of water for triggering conditions than shallower landslides. For the cases of Java, most of deep-seated landslides can be produced by an antecedent rainfall more than $600 \mathrm{~mm}$ without any rain shower during landslide day, and the majority of shallow landslides were triggered by antecedent rainfall between $225 \mathrm{~mm}$ and $625 \mathrm{~mm}$.

Classified as the most populated island in the world and the problem of land shortage, Java involves the human factors on landslide triggering. Indicators that could reflect the intensity of human intervention on the territory include the high rate of population increase in Java. As population pressure increases, not only will the stability of the slopes be reduced, but people will also be forced to cultivate even more unstable slopes. As a consequence of both, the risk on damage by slope failure increases. For the case in Java, this human pressure aggravates the abrupt land use change from forested land to dryland agricultural area which is the host of the most landslides in Java. Other results 
in several parts of the world confirm that the human pressure and deforestation play an important role on landslide triggering (van Beek, 2002; Glade, 2003; Knappen et al., 2006).

\section{Conclusion}

Java Island experiences a lot of landslides which cause enormous casualties and damages. The high recurrence of landslides in Java is controlled both by natural and human factors which are compounded in Java. As a wet tropical region, abundant rainfalls occurring on deep weathered materials situated in mountainous region triggered many landslides in Java. Indeed, high human interference also aggravated slope failures: forest clearance, excavating foothills and cutting hillsides for increased road and settlement constructions for agriculture areas has increased rapidly. However, integrated spatio-temporal landslide studies to understand this problem are still limited. This paper contributes an analysis of a set of information for all Java concerning landslides behaviour and their controlling factors. This work should be of value to the government mitigation program as well as being helpful in developing a landslide hazard and risk assessment model for the area.

\section{Acknowledgement}

We acknowledge to Geological Agency Ministry of Energy and Mineral Resources for providing the landslide data, Research Centre for Disasters, Faculty of Geography Universitas Gadjah Mada for providing the support during field survey. We wish to thank Prof. Michael James Crozier (Victoria University of Wellington, New Zealand) for his very useful comments and corrections on an earlier version of this paper.

\section{References}

Alaya IA (2004) Hazard assessment of rainfall-induced landsliding in Mexico. Geomorphology. $22 \mathrm{p}$.

Brunsden D, Ibsen ML, Lee M, Moore R (1995) The validity of temporal archive records for geomorphological processes. Quaest Geogr 4:79-92 (special issue)

BPS (2005) Statistik Indonesia 2005/2006. Available online at https://bps.go.id/index.php/ publikasi/3595

Crozier MJ (1999) Prediction of rainfall-triggered landslides : a test of the antecedent water status model. Earth Surf. Process. Landforms 24, 825-833

Dai, FC, Lee, CF (2002) Landslide characteristics and slope instability modeling using GIS, Lantau Island, Hong Kong. Geomorphology 42: 213-228.

Devoli G, Morales A, Høeg K (2007) Historical landslides in Nicaragua - collection and analysis of data, Landslides 4:5-18

DVGHM (2006) Situs internet dari Direktorat Vulkanologi dan Mitigasi Bencana Geologi [WWW Document] URL http:/ / www.vsi.esdm.go.id/

Gabet EJ, Burbank DW, Putkonen JK, Pratt-Sitaula BA, Ojha T (2004) Rainfall thresholds for landsliding in the Himalayas of Nepal. Geomorphology $63: 131-143$

Glade T (2003) Landslide occurrence as a response to land use change: a review of evidence from New Zealand, Catena 51: 297- 314

Guzzetti F, Ardizzone F, Cardinali M, Galli M, Reichenbach P, Rossi M (2008) Distribution of landslides in the Upper Tiber River Basin, Central Italy. Geomorphology 96 : 105 - 122

Hadmoko, DS (2006) Les mouvements de terrain dans les Monts Menoreh : déclenchement, dynamique, aléa, modélisation spatio-temporelle et risques associés, MSc. Thesis, Université Paris 1, Panthéon Sorbonne, France. 83 pp. (unpublised).

Hadmoko, D.S., Lavigne, F., Sartohadi, Winaryo (2010) Landslide hazard and risk assessment 
and their application in risk management and landuse planning in eastern flank of Menoreh Mountains, Yogyakarta Province, Indonesia. Natural Hazards 54, pp 623-642.

Hadmoko, D.S., Lavigne, F. Samodra, G. (2017) Application of a semiquantitative and GISbased statistical model to landslide susceptibility zonation in Kayangan Catchment, Java, Indonesia. Natural Hazards (article in press).

Iida T (1999) A stochastic hydro-geomorphological model for shallow landsliding due to rainstorm. Catena 34, 293-313.

Knapen A, Kitutu MG, Poesen J, Breugelmans W, Deckers J, Muwanga A (2006) Landslides in a densely populated county at the footslopes of Mount Elgon (Uganda): Characteristics and causal factors, Geomorphology 73 : 149-165

Lavigne F, Gunnell Y (2006) Recent land cover change and abrupt environmental impacts on Javan volcanoes, Indonesia. Regional Environmental Change: 6, 1-2, 86-100.

Paudel PP, Omura H, Kubota T, Inoue T (2007) Spatio-temporal patterns of historical shallow landslides in a volcanic area, Mt. Aso, Japan. Geomorphology $88: 21-33$

Petley DN, Heam GJ, Hart A, Rosser NJ, Dunning SA, Oven K, Mitchell WA (2007) Trends in landslide occurrence in Nepal. Nat Hazards 43:23-44 DOI 10.1007/s11069-006-9100-3

Rahardjo H, Li XW, Toll DG, Leong EC (2001) The effect of antecedent rainfall on slope stability. Geotechnical and Geological Engineering 19: 371-399

Samia J, Temme, A, Bregt A, Wallinga J, Guzzetti F, Ardizzone F, Rossi M, (2017) Do landslides follow landslides? Insights in path dependency from a multi-temporal landslide inventory. Landslide 14: 547 - 558

Saputra A, Sartohadi J, Hadmoko DS, Gomez C (2016) Geospatial Assessment of Coseismic Landslides in Baturagung Area. Forum Geografi 29, 99-114.

Schuster RL, Highland LM (2001) Socioeconomic and environmental impacts of landslides in the western hemisphere. USGS Open-File Report, 01-276

Southeast Asia Association of Seismology and Earthquake Engineering (SEASEE) (1985) Series on Seismology. Arnold (ed.)Washington D.C.: Government Printing Office.

Spiker EC, Gori PL (2003) Partnerships for reducing landslide risk: assessment of the national landslide hazards mitigation strategy. The National Academy of Sciences Press, Washington,DC

Van Asch TWJ, Buma J, Van Beek LPH (1999) A view on some hydrological triggering systems in landslides Geomorphology 30: 25-32

Van Beek LPH (2002) The effect of land use and climatic change on slope stability in the Alcoy region (Spain), Thesis, Faculty of Geographical Sciences, Utrecht University, The Netherlands, 363 pp.

Zhou CH, Lee CF, Li J, Xu ZW (2002) On the spatial relationship between landslides and causative factors on Lantau Island, Hong Kong. Geomorphology 43 : 197- 207

Zhou G, Esaki T, Mitani Y, Xie M, and Mori J (2003) Spatial probabilistic modeling of slope failure using an integrated GIS Monte Carlo simulation approach. International Journal of Engineering Geology 68: 373-386. 